\title{
_Equipment and Products
}

\section{CHROMITE RECOVERY FOR FOUNDRIES}

Foundry and Technical Liaison Ltd. has developed a separator to recover chromite from mixed silica backing sand in foundries producing high-quality steel castings. The machine consists of two stages of high-intensity permanent magnet separation. In the first stage pieces of metal and sand/metal agglomerates are removed from sand. In the second stage chromite is recovered for return to the casting process. The treated silica is then returned to the conventional return sand treatment line. Processing rates of up to $5 \mathrm{t} / \mathrm{h}$ have been achieved.

\section{SUPERCONDUCTING MAGNETIC BEARING}

A superconducting magnetic bearing has been developed by Superconductivity Research Laboratory and Nippon Seiko KK. The bearing in which a rotor weighing $2.4 \mathrm{~kg}$ can spin at a rate of $30000 \mathrm{rpm}$, utilizes a pinning force between an $\mathrm{Y}-\mathrm{Ba}-\mathrm{Cu}-\mathrm{O}$ superconductor and a magnet. The $\mathrm{Y}$-based superconductor has a critical temperature of $77 \mathrm{~K}$.

Reportedly, the new achievement is almost within reach of practical application and could find uses in those areas where high-speed rotation is required.

\section{HIGH SILICON STEEL}

NKK developed the technology for the first commercial- scale production of $6.5 \%$ $\mathrm{Si}$ steel sheets. The new product, available in coils and sheets has excellent magnetic properties: ten times greater permeability and one eighth the magnetostriction, compared to $3 \%$ Si steel. 


\section{SALES OF RARE-EARTH MAGNETS CLIMB}

Global sales of Nd-Fe-B permanent magnets reached US\$360 million in 1990 and are expected to climb to $\$ 2.7$ billion by the year 2000 .

The Japanese production of rare-earth magnets increased in the first half of 1991 by $20 \%$ over the same period of 1990 . The rate of growth is likely to fall in the second half of 1991 because of lower demand from the computer disk industry. The rate of growth is likely to fall below $10 \%$ in late 1991 .

In 1991, production of Nd-magnets, which account for around $60 \%$ of output of rare-earth magnets, is estimated at 520 t. In 1991 increasing demand for Ndmagnets will more than offset the decline in consumption of Sm-Co magnets. Production of rare-earth magnets is estimated to increase by $20 \%$ to $862 \mathrm{t}$ in 1991 and by $10 \%$ to around $950 \mathrm{t}$ in 1992 . As a result, all major Japanese producers of rare-earth magnets are reducing output of $\mathrm{Sm}-\mathrm{Co}$ magnets and raising production of $\mathrm{Nd}-\mathrm{Fe}-\mathrm{B}$ magnets.

It is predicted that the value of Japanese production of rare-earth magnets will exceed that of ferrite magnets in 1992. Japanese production of permanent magnets in 1990 and 1991 is reviewed in the following Table.

$\begin{array}{llll}\text { Volume (t) } & & \text { Value (mill Yen) } \\ 1990 & 1991 & 1990 & 1991\end{array}$

Cast magnets

959

841

3832

3442

Ferrite magnets

40332

40323

28420

28306

Rare earth magnets

717

862

22541

26216

Others

5

6

276

319

Total

42013

42032

55069

58283 